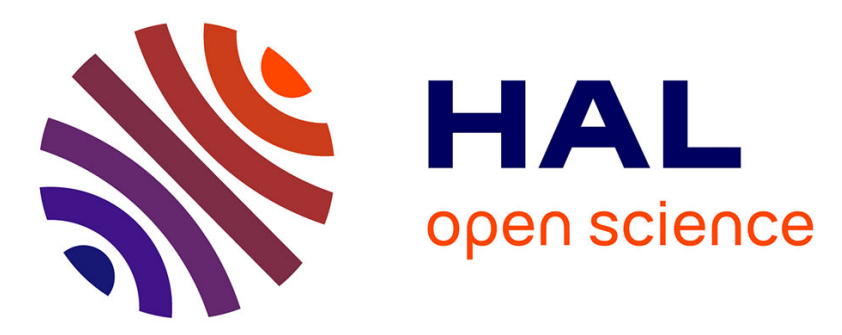

\title{
JOINT COMMITMENT, COERCION AND FREEDOM IN SCIENCE Conceptual Analysis and Case Studies
}

Alban Bouvier

\section{- To cite this version:}

Alban Bouvier. JOINT COMMITMENT, COERCION AND FREEDOM IN SCIENCE Conceptual Analysis and Case Studies. JEROEN VAN BOUWEL. THE SOCIAL SCIENCE AND DEMOCRACY, Palgrave, pp.143 - 161, 2009. ijn_01081452

\section{HAL Id: ijn_01081452 \\ https://hal.science/ijn_01081452}

Submitted on 7 Nov 2014

HAL is a multi-disciplinary open access archive for the deposit and dissemination of scientific research documents, whether they are published or not. The documents may come from teaching and research institutions in France or abroad, or from public or private research centers.
L'archive ouverte pluridisciplinaire HAL, est destinée au dépôt et à la diffusion de documents scientifiques de niveau recherche, publiés ou non, émanant des établissements d'enseignement et de recherche français ou étrangers, des laboratoires publics ou privés. 
$<$ published, with a few changes, in Jeroen van Bouwel (ed.), The social sciences and democracy: How philosophy of science informs us about their relation, Palgrave, 2009, pp. 143-161>

\title{
JoInt COMMITMENT, COERCION AND FREEDOM IN SCIENCE Conceptual Analysis and Case Studies
}

\author{
by \\ Alban BOUVIER \\ Institut Jean Nicod (ENS/ EHESS/ CNRS , Paris)
}

This paper deals with the Ethics of group life in the sciences, if not directly with the policy of science that might evolve from it, and more precisely with the issue of democracy within scientific life. ${ }^{1}$

I uphold a "naturalized" conception of ethics in the moderate sense that I consider a relevant formulation of moral norms (like the duty of respect towards others) has to be illuminated by a close analysis of the effective social life (although not reduced to it). This viewpoint is compatible with a "naturalized" conception of social epistemology, understood as a formulation of the norms of knowledge (like logical and empirical validity norms) close to the effective processes of scientific life (Goldman, 1999, 2002; Thagard, 1998a, 1998b). ${ }^{2}$ Consequently this ethical and epistemological study would like to contribute to the sociology of knowledge in Robert Merton's (1942) style as well, aiming at characterising the "ethos of science", that is not only the effective standards of scientific life but the ideal moral norms of science and reciprocally.

My starting point is the idea that contractualist models are relevant both for the analysis of the effective structure of scientific groups, that is at the descriptive level, and for providing reasonable normative guides of scientific ethos, but to an extent that has to be carefully investigated. My main point is to address the general issue of the nature and the degree of freedom that is both ethically desirable and pragmatically accessible within a research team.

In the first part of this paper, I set forth two very different kinds of situations regarding the freedom issue in science, although both can be considered as based on "joint commitments". In the second part, I argue that many situations that seem to be based on joint commitments, which implies reciprocal and interdependent commitments, are actually based instead on mere unilateral commitments and that those may involve different kinds of ethically illegitimate constraints (or coercion). In the third part, I compare the concepts of joint commitment (Margaret Gilbert) and positive liberty (Isaiah Berlin), both inherited from Rousseau's contractualism. Rejecting positive liberty as well as negative liberty as unrealistic, I argue for the significance of a third conception of liberty as "absence of domination" (Philipp Pettit). I uphold that it is a reasonable ideal in scientific life.

\footnotetext{
${ }^{1}$ Regarding the place and the role of science in democratic states, which is another topic, see e.g. Kitcher (2001). And for the more general issue of ethical values in science, see e.g. Longino (1990, 2002).

${ }^{2}$ See also Longino $(1990,2002)$ on a similar conception of social epistemology and ethics in science.
} 
I.

\section{UNCONSTRAINED AND CONSTRAINED JOINT COMMITMENTS}

IN SCIENTIFIC LIFE.

I first contend that recent contractualist models of groups like Margaret Gilbert's or Philip Pettit's may be useful for analysing effective scientific groups, therefore at the pure descriptive level, whatever normative may be the main concern of each of them. Nevertheless I will mainly consider Gilbert's account in this first part of my analysis, since Gilbert has devoted an illuminating paper specifically to scientific life. $^{3}$

Margaret Gilbert has implicitly put forward an alternative to Kuhn's account of paradigms. ${ }^{4}$ For the most part of his account of scientific progress, Kuhn examined the transmission of scientific principles during periods of "normal science", when the scientists learn the principles by doing typical exercises and repeating classical experiments within the paradigm at least as much as by explicit teaching. In these situations, there might be no real space for discussion since discussion requires clear awareness of the principles at stake. Kuhn's account of scientific life fits in with witnesses' accounts like Heisenberg's. Thus, according to a recent historian of Quantum Mechanics, Mara Beller (1999), Heisenberg conceded in his preface to "his 1930 book, which he dedicated to the 'diffusion of the Copenhagen spirit', that 'a physicist more often has a kind of faith in the correctness of the new principles than a clear understanding of them"' (p. 39). Actually, to use J. Cohen's (1992) distinction between belief and acceptance as respectively a passive and an active mental process, one can argue that within Kuhnian "normal science", scientists often have "beliefs", whereas in revolutionary periods, when a new paradigm arises, scientists have to choose between two paradigms and "accept" one of them after having weighed pros and cons. Mara Beller's commentaries on Heisenberg's confidence makes this distinction particularly clear, even if Beller does not herself use Cohen's concepts: "Young physicists, who streamed into these centers [Copenhagen, Göttingen, Leipzig, Hamburg] from all over the world, were exposed automatically [= "belief"] to the new philosophy. Because they were more interested in calculating and obtaining definite results than in philosophizing, most of them simply adopted [= "belief"] the official interpretation without deep deliberation [= without "acceptance"]" (p. 39) (commentaries between brackets are mine). Such deliberation would have been necessary, on the contrary, if students had been exposed both, on the one hand, to either Bohr (who directed the Copenhagen Institute), Born (who was teaching in Göttingen), Heisenberg (who conducted research in Göttingen, then in Copenhagen, then in Leipzig) or Pauli (who conducted research in Göttingen, then in Copenhagen, then in Hamburg), and on the other hand, to Schrödinger, who developed an alternative conception of Quantum Mechanics in a different place (Berlin). ${ }^{5}$

\footnotetext{
${ }^{3}$ See Gilbert (2000).

${ }^{4}$ I have not found any explicit references to Kuhn in Gilbert's work.

${ }^{5}$ Kuhn himself insists only on passive aspects ("belief") of science, even during revolutionary periods, as if the change was due to a religious conversion (then from one "belief" to another "belief"). But this account of paradigm shift seems psychologically quite implausible, even if some passive processes can play a role, like new perceptual experiences. Besides, it is important to notice that the Copenhagen school is sometimes regarded as the main historical example on which Kuhn would have constructed the notion of paradigm (Hanson, 1958, Beller, 1999).
} 
Gilbert (2000) suggests that new paradigms usually emerge not from the only addition of multiple individual acceptances but instead from the "joint acceptances" and even "joint commitments" of scientists. ${ }^{6}$ As is now well known, Gilbert's main goal has been to try to make sense of Durkheim's intuitions that there are collective ideas which can be different from individual ideas and that these collective ideas can exert a constraint upon the individuals in the sense that the individuals might not be free to not profess them. Gilbert $(1989,2006)$ suggests that, at least in certain cases, it might be comparable to a contractualist situation where certain people vote against a law but must nevertheless accept it as their law and obey it if the majority has voted in favour of the law. Everybody is "committed" to obey the law and, more exactly, is "jointly committed" since each of the voters contracts with each other by voting and votes only under the condition that everyone does the same (thus, their commitments are interdependent). Gilbert claims that there are many situations in which there is not a formal and explicit contract but nevertheless a kind of implicit contract. For example, somebody may speak on behalf of the group as a self-proclaimed spokesman in such a way that everybody feels jointly committed to this leader and the other members of the group just because they did not explicitly disagree when he spoke, even if they do not agree deeply (Gilbert, 1994).

Gilbert did not write much on scientific collective beliefs - or acceptances and, in her 2000 paper, she was essentially interested in the specific issue of the positive role of outsiders on the growth of knowledge, insofar as group commitments around a paradigm can hinder scientific progress. Thus, she was not interested in the general relevance of the joint commitment model for investigating the social scientific life. I claim that Gilbert's extension of the contractualist model to situations where there is not an actual contract is especially interesting because it is much more realistic (Bouvier, 2008). ${ }^{7}$ In fact, it is rare there be an explicit contract relating to a paradigm or a research programme in the sciences. It might be the case when there is a public manifesto and the content of the manifesto is voted on by all the members of the group that supports it or by a similar formal procedure. But manifestoes are rare in the sciences, in particular in the natural sciences, and when there are such things, they are rarely the result of a formal procedure. ${ }^{8}$

As Paul Thagard has noted, "in most scientific fields (...), there is no central social mechanism that produces a consensus" (Thagard, 1998b). Nevertheless, Thagard adds: "In medical research, the need for a consensus is much more acute, since hypotheses $(. .$.$) have direct consequences for the treatment of patients". Then, Thagard$ refers to the consensus conferences that exist in many countries on health issues. Thus, in the US, the National Institute of Health regularly convene such conferences.

${ }^{6}$ Gilbert does not use "acceptance" and "belief" in Cohen's technical sense and she is even reluctant to this use, proposed by Meijers (1999) and Wray (2001). I do not elaborate on this discussion, which does not really matter here. I just deem that Cohen's concepts clarify issues at stake here.

${ }^{7}$ Nevertheless, one of my goals in this paper is to set forth the case that this model is still not realistic enough.

${ }^{8}$ An example of an explicit collective manifesto, in the same historical context as the Copenhagen School, is the Vienna Circle manifesto, but this dealt with the most general philosophical bases of science rather than with a specific research programme in science. Another example is the first chapter of Bourbaki's Éléments de mathématique, but this case is not easy to investigate since the Bourbaki group cultivated so much secrecy about its functionning that even the identity of its members was hidden. 
These conferences are constituted by a panel of experts on a specific issue (e.g., given the new results in sciences, what is the most recommendable treatment of gastric ulcer?). The panels take a decision after a two or three day deliberation. Deliberating is justified in these medical contexts because ambiguous data are frequent. Thus, as Thagard has reported, many gastric ulcers were sensitive to antibiotics but not all and, furthermore, the antibiotic treatment needed a tri-therapy, which was much more costly than the previous therapy. Consequently, a consensus conference appeared to be quite useful in order to take the right decision on the best remedy for gastric ulcers. ${ }^{9}$

The situation is comparable in other domains such as economics, because practical advice is at stake as well. Thus institutes (private institutes), such as the von Mises and von Hayek Institutes or the Mont Pélerin Society (all of them founded in line with the viewpoints of the Austrian School of Economics, to which I will later on go back regarding other aspects), give political recommendations based on a certain conception of how economics functions, an issue that remains uncertain. In such cases, on which I don't want to elaborate in detail, one often encounters situations in which the members of a minority have to "jointly accept" (with the majority) the claims of the majority, although they personally disagree with these claims. Consequently, the minority members will necessarily feel the group as constraining. But this constraint is implied by democratic procedures and consequently might be encountered in any acceptance of a democratic procedure.

As Thagard states, in most fields the practical implications are not so evident, so that the situation is quite different. However, in this field as in others fields, one can encounter implicit contract situations. There may be sorts of informal deliberation between the members of a group, for example on the general principles of a research programme. But, in these latter cases, even if one considers that, in principle, contracts require from each participant a clear awareness both of what is contracted and of the existence itself of a contract, ${ }^{10}$ in fact situations are often so ambiguous that it may turn out that certain individuals happen to be committed against their deepest will, then more or less forced to commit. ${ }^{11}$ I will take here two historical examples to set forth the plausibility of these situations in sciences and to more clearly distinguish between the two kinds of constraints or coercions (one relative to any joint commitment procedure and one not). Certain differences may seem psychologically or sociologically very minor but I claim that they make sense ethically.

First, when Emile Durkheim and Marcel Mauss (1903) founded a new sociology of knowledge research programme in a memoir they signed together (the sociology of the fundamental categories of thought programme), although they did not really set forth their aims in a manifesto, their joint memoir nevertheless sounded like a mani-

\footnotetext{
${ }^{9}$ Unlike Thagard, Beatty (2006) explicitly uses Gilbert's concept of “joint acceptance” to account for similar collective medical recommendations (in this case, regarding the appreciation of genetics hazards of radiation exposure). Referring to Gutman and Thompson (2004), Beatty also tackles the issue of deliberation as a relevant decision-making procedure in such cases.

${ }^{10}$ Gilbert would say that this is a common knowledge context.

${ }^{11}$ Even explicit contracts may be more or less constrained, e.g. when participants in a discussion do not dare to oppose a leader. But it is still more likely when the contract is implicit.
} 
festo. Besides, no politically oriented academic society or institute was founded on their theoretical ideas (unlike what happened in the Austrian School case), but nevertheless they appear to have been explicitly committed, as in a contract, with regards to this programme. Thus, they constituted a "group" or, as Gilbert says, a "plural subject". Furthermore they very probably also discussed at length about the content of this programme, although one does not have any direct evidence (e.g. via letters) of that. They very probably deliberated on the relevance of referring to such or such theoretical principle and promoting such or such scientific goal, in the sense that deliberation is an exchange of arguments leading to a decision. Consequently, the programme was coherent, which means in particular that it did not look like a mere juxtaposition of two more or less different programmes, as happens in a syncretic synthesis obtained as a result of a mere negotiation. ${ }^{12}$

In this case, if either Durkheim or Mauss might have felt constrained by the result of the common deliberation (to some extent possibly different from their deep thoughts), and even if Mauss, as a junior, was more susceptible to have renounced personal ideas than Durkheim as a senior, ${ }^{13}$ at least one does not have any evidence that Mauss was compelled to "jointly commit" to any common programme with Durkheim.

Finally, this programme was meant to give orientations to a team of colleagues and younger researchers like Hubert, Hertz, Czarnowki and so on. These individuals did not participate in the writing of the programme, and neither explicitly added their name to the "manifesto". But, they joined the first two, mainly through participating regularly in the writing and editing of L'Année Sociologique. Thus, with them they were also (almost explicitly) jointly committed to this programme. ${ }^{14}$ But there is no evidence either that they had been more or less forced to commit either to this specific programme or to any collective programme.

Thus, the Paris French School is a particularly clear example of a group of scientists who intellectually seem to have been jointly committed, in the contractualist sense of this expression, either in an explicit (Durkheim and Mauss signing a joint memoir) or in a quasi-explicit way (the other members participating in the journal of the French School, l'Année sociologique). A particularly striking feature of this group behaviour is that they happened to say "we" when they expressed ideas of the joint programme, even in personal papers. In these contexts, they publicly meant that they felt committed with the other members of the group even while expressing their own ideas and that they felt also intitled to involve the other members in their writings, to some extent at least, given that these members were supposed to be reciprocally and interdependently committed to the same common research programme. Marcel Mauss, in a lecture given as the 1938 Huxley Memorial Lecture, wrote: "Vous verrez un échantillon - peut-être inférieur à ce que vous attendez - des travaux de l'école

\footnotetext{
${ }^{12}$ About the difference between deliberation and negotiation (or "bargaining"), see Elster (1991).

${ }^{13}$ In fact, all the witnesses state that, while Durkheim always exerted enormous and almost totalitarian pressure upon Mauss (who was his nephew) to work more and more for the Année Sociologique, to the detriment of Mauss's private life, that was only (or at least mainly) institutional pressure or "coercion" (Besnard, 1979).

${ }^{14}$ Gilbert $(1996,2006)$ shows convincingly how someone can jointly commit with other people who have previously jointly committed together.
} 
française de sociologie". ${ }^{15}$ And he added : "Nous nous sommes attachés tout spécialement à l'histoire sociale des catégories de l'esprit humain" (Mauss, 1950, p. 334). ${ }^{16}$ In this context, "we" is not a conventional way to say "I" but clearly refers to the whole "French school of sociology", as the context shows. In the same paper, Mauss summarized the contributions of Hubert, Czarnowki, Durkheim and Lévy-Bruhl to the joint enterprise.

I borrow the second example again from the history of the Copenhagen group in Quantum Mechanics, but I now focus on the famous 1927 lecture Niels Bohr gave in Como, Italy at the International Volta Congress, in which he put forward the "complementary principle." Speaking about the same period we have referred to above, Heisenberg wrote that there was a kind of specific "spirit" in Copenhagen in these late twenties. Beller adds that in the early thirties it was the case as well not only at Copenhagen but as well at Göttingen, and still slighty later on at Leipzig and Hamburg, where respectively Heisenberg and Pauli had been given professorships. At this time, this "spirit" appears to have been just a "passive" belief. But, it was not yet the case in September 1927, in Como (at the Volta Congress) or in Brussels in October of the same year (at the Solvay Congress), that is at the very beginning of the so-called "Copenhagen school".

According to Mara Beller, at Como, Bohr did not want only to express his ideas but also the ideas of the Copenhagen group. This group was constituted of physicists working together in Copenhagen in the same Institute or regularly meeting there, mainly Heisenberg, Pauli and Dirac. Bohr's talk also involved other physicists closely connected to the others, such as Max Born (Heisenberg and Pauli had been his assistants in Göttingen) or Jordan (another of Max Born's assistants). Bohr even wanted to reconcile the stance of his team with Schrödinger's, someone who was to some extent an intellectual enemy. Thus, it resembled a collective manifesto, with somebody speaking on behalf of the group. However, Bohr was not formally delegated by the group to take on this role, and the group members did not write the text together (as Durkheim and Mauss) or deliberate on the different issues at stake (e.g. on the meaning of "complementarity" or on Niels Bohr's attempt to reconcile Quantum Mechanics and classical physics). But, as neither Heisenberg nor Pauli explicitly and publicly disagreed with Niels Bohr's lecture either at Como or in further papers, the complementary principle was perceived by the entire community as the Copenhagen School interpretation of Quantum Mechanics. ${ }^{17}$ However, one knows explicitly from the correspondence of these authors and implicitly from their articles that actually some of them, especially Heisenberg, did not accept the complementary principle at all (Beller, 1999, Howard, 2004). Moreover, none of the junior scientists explicitly jointly committed to Bohr's programme by participating in a specific review (like the members of Durkheim's group) or a handbook. Thus, in this situation it appears that, unlike the young members of the French School of Sociology vis-à-vis Durkheim,

15 "You will see a sample - maybe not as good as what you might have expected - of works of the French School of Sociology".

16 "In particular we have tackled the social history of categories of the human mind"

${ }^{17}$ Dirac could not come to Como (nor Schrödinger). 
Heisenberg and Pauli were forced - to some extent - to jointly commit to Bohr and to assume a collective paradigm (of which they did not personally accept certain ideas). ${ }^{18}$

Nevertheless, from Gilbert's point of view as we will soon see in more detail, this makes no real significant difference with the French School example since the public silence of the Copenhagen group members was to be interpreted as a joint agreement by every participant in the Congress, so that the Copenhagen group members were jointly committed exactly in the same sense as the Paris group members According to me, on the contrary, the point here is that, if the intellectual joint commitment itself (whatever its specific content may be) was obtained only thanks to a kind of coercion, this commitment raises specific problems.

Actually, one could argue that the involvement of the other Copenhagen and Göttingen physicists was not yet as clear as it was in the Paris group case. Thus, in his Como talk and in the different written versions that were published from this, Niels Bohr never used "we" (unlike Mauss, for example), as he could have done if he wanted to very clearly implicate the Copenhagen-Göttingen group as such. ${ }^{19}$ However, one month later, at the end of the Solvay Congress, Heisenberg and Max Born gave a joint lecture, in which they pronounced this famous statement: "We regard quantum mechanics as a complete theory for which the fundamental physical and mathematical hypotheses are no longer susceptible of modification." (Heisenberg W. and M. Born, 1927, p. 437) ${ }^{20}$ In the context, it was clear that "we" did not refer only to Heisenberg and Born but instead to the whole Copenhagen-Göttingen group. And as Bohr did not explicitly disagree with the content of this paper, the usual feeling was again that all the Copenhagen-Göttingen physicists shared the same conception of Quantum Mechanics. ${ }^{21}$ At Solvay, it is Heisenberg and Born who were the autoproclaimed spokesmen and who more or less forced the others members of the Copenhagen-Göttingen group (ironically including Bohr himself) to accept their own common view. Then, all the scientists were publicly jointly committed to a common conception like in Como, although not exactly to the same conception as in Como, since they did not explicitly disagree. ${ }^{22}$

${ }^{18}$ See also Bouvier, (2004 and 2007a). The case of Pauli is particular because Pauli participated very much in the re-writing of Bohr's paper between the Como talk and the various further publications, but not to the point of becoming a joint author with Bohr (like Durkheim and Mauss). The different versions of this paper were only signed by Bohr.

${ }^{19}$ My account of the Bohr's Como lecture is based on the 1931 version, a revised version of the paper published in Nature in 1928, and the version to which scholars usually refer. The original oral version was not completely written down; consequently it is not available (Mehra J. and H. Rechenberg, 1982).

${ }^{20}$ I thank Orly Shenker for this reference.

${ }^{21}$ The main discussions at the 1927 Solvay Congress were held between Bohr and Einstein (who was very reluctant about Bohr's ideas on ontological indeterminism). Pauli participated very much in the discussion as well but there was no space for an internal discussion (or deliberation) within the Copenhagen group or within the slightly broader Copenhagen-Göttingen group. See Mehra J. and H. Rechenberg, (1982) for further details.

${ }^{22}$ Howard (2004) contends that what is now called the "Copenhagen interpretation" is actually very close to Heisenberg's conceptions (namely the subjective interpretation of quantum phenomena, focusing on the observer's role) and that it is a very regrettable mistake to attribute this conception to Bohr. Howard adds that Heisenberg presented himself explicitly as a spokesman of the whole Copenhagen group mainly from the fifties onwards (and that he might have specific personal interests in giving the impression that there was a unified interpretation shared by everyone in the Copenhagen group, and that he was really a member of this group, given that his very ambiguous behaviour during the Second World War regarding the Nazi nuclear programme had almost caused him to be banished from this group). The quotation drawn from Heisenberg and Born's report at Solvay reveals that it was already the case in 1927. 
What can be considered as a consequence of the Como coerced joint commitment and of the related absence of deliberation between the group members is that the Como talk is notoriously obscure. ${ }^{23}$ Admittedly there are several interpretations of this obscurity. The most classical one is that Bohr's ideas were not yet clear enough when he wrote this paper and that he gave the audience his still emerging thought both on the relevant interpretation of Quantum Mechanics and on the unification of contemporary theoretical physics. ${ }^{24}$ But Mara Beller's recent interpretation is that Bohr tried to amalgamate his ideas with Heisenberg's, Dirac's, and Pauli's. Since their ideas were incompatible on certain fundamental points (which was not the case, e.g. in the Durkheim-Mauss memoir on the sociology of categories), Niels Bohr's amalgamating could not be but an incoherent syncretic synthesis.

To conclude the first part of this investigation, I will just state again that there is a pretty clear opposition between a freely agreed joint commitment (within the Paris school of sociology) and a forced joint commitment (within the Copenhagen school of Quantum Mechanics). Although from Gilbert's viewpoint this does not make a relevant difference, one can argue that many scientists would not find Niels Bohr's attitude at Como (as described above, following Beller's interpretation) or Werner Heisenberg's and Max Born's at Solvay quite fair in comparison with Emile Durkheim's relation to Marcel Mauss and the members of the Paris group. I share this feeling and, in the second part of this paper, I would like to focus on the ethical dimension of Gilbert's conception of joint commitment a little more directly .

II.

JOINT COMMITMENT, UNILATERAL COMMITMENT

AND ILLEGITIMATE CONSTRAINTS

To my knowledge Gilbert has not elaborated at length on the previous normative problem (either in scientific life or elsewhere) and when she has addressed it, it was in relation with a closely related although different problem. It deals with Hobbes' and Rousseau's conceptions of social contract. In fact, provoking Rousseau's indignation, Hobbes' viewpoint left the door open to an ethical justification of domination and slavery _ as far as this relation is "jointly accepted" (and that each contractant, either master or slave, feels "jointly committed"). ${ }^{25}$

Commenting Hobbes's conception of social contract, David Schmidtz (1990), whom Margaret Gilbert (1993) quoted, wrote : "I think it is more charitable to Hobbes to read his discussion as a purely descriptive account of the possible ways in which sovereigns can actually emerge, with no normative implications intended" (Gilbert, 1993, p. 310, n. 44). But, responding to Schmidtz, Gilbert added after

${ }^{23}$ Similarly, one can argue that a consequence of the Solvay forced joint commitment is that sometimes Heisenberg's specific ideas (for example the subjectivist interpretation of Quantum Mechanics) are attributed to Bohr, cf. the previous footnote.

${ }^{24}$ Nevetherless most scholars think that the obscurity of this principle still grew as Bohr broadened its significance in his later publications.

${ }^{25}$ See, e.g., Rousseau (1964) Livre I, chap. IV « De l'esclavage ». 
Schmidtz' quotation: "My dispute is with 'no normative implications'. No moral implications of a certain sort, perhaps. But (...) any genuine agreement has its own normative weight - as the conquering sovereign may well discern" (p. 310, n. 44). ${ }^{26} \mathrm{I}$ agree with Gilbert on the fact that there is still a normative constraint or, more exactly, that people may feel committed (or may feel the "normative weight" of the agreement), even when there is constraint or coercion on the commitment itself, that is when participants have been to some extent compelled to jointly commit. And I find her viewpoint particularly astute and right sociologically speaking. ${ }^{27}$ But, regarding the moral issue, I find Gilbert much too ambiguous. In fact, she seems to only concede that the commitment might not have moral legitimacy ("perhaps") and even to suggest that the same commitment might nevertheless have certain moral legitimacy, although of another sort than those Schmidtz seems ready accept ("no moral implications of a certain sort"). According to me, Gilbert's response remains much closer to Hobbes's ambiguous viewpoint than to Rousseau's intuitions, which I consider (probably like many other people) as the genuine moral intuitions. I will try to make this point more explicit regarding the scientific life case. Again, historical examples can help us to understand what is really at stake in these contexts.

Actually, to be perfectly clear, one has to carefully distinguish between two kinds of constraining situations. What might be revolting is a situation where the participants in a joint commitment are more or less forced to jointly commit, as at Como, that is a specific contractualist procedure. This was the matter in the first part of this paper. But it might be also the content of the contract, especially when this contract implies entirely imposed constraints (slavery is an extreme case), something Philip Pettit calls "domination". This is the matter of Hobbes-Rousseau controversy. Not surprisingly, the two constraints might find themselves entangled in historical cases.

But a careful investigation suggests that joint commitment, therefore reciprocal and interdependent commitments, may be less frequent in sciences than Margaret Gilbert seems to believe (and that Gilbert's concept of joint commitment may lead one to think), whereas unilateral commitments may be much more frequent. Scientific groups are generally constituted of junior and senior researchers, so that it is likely that the commitment of each member with regards to a set of principles will not be reciprocal and interdependent: the senior will more likely expect a commitment from the junior to a set of principles without feeling committed with him to this set of principles. ${ }^{28}$ As some examples will illustrate, the expectation of such commitment might be very constraining. Consequently, the examination of ethically illegitimate commitments deserves to be extended to these unilateral commitments. One will observe constraints both on the commitment content and on the commitment procedure (which this time means constraint to unilaterally commit). I will in succession investigate two different examples illustrating the two different situations. To facilitate comparisons, I chose these examples in scientific communities that I have already considered.

\footnotetext{
${ }^{26}$ Gilbert also discusses Simmons (1979) and Simmons (1984). See also Gilbert (2006).

${ }^{27}$ Gilbert's analysis fits in with Weber's analysis of legitimation, which permits us to understand how (even authoritarian) political powers can stand up without necessarily using force or even threatening to use force.

${ }^{28}$ The case of Durkheim, as described above, might be an exception.
} 
Let us first refer to the relations Bohr had years later after the Como conference with his students or young researchers. Beller insists on the fact that Bohr was now considered as a "hero" and was surrounded by a true cult to the extent that the young researchers did not feel able to think differently from Bohr and tried to interpret his most obscure papers as if they expressed the hidden truth of the world. Thus, according to Mara Beller, Weizsäcker once noted, after having met Bohr and understood hardly anything, "What must I understand to be able to tell what he meant and why was he right? I tortured myself on endless solitary walks" (Beller, 1999, p. 275). Weizsäcker's reaction seems to be pretty irrational since Weizsäcker seems a priori to eliminate the possibility that Bohr could have been wrong. ${ }^{29}$ Beller comments : "The question was not: Was Bohr right? or To what an extent was Bohr right? or On what issues was Bohr right? But quite incredibly, What must one assume and in what way must one argue in order to render Bohr right?" (Beller, 1999, p. 275). Thus it looks like an entire submission to one another's thought and therefore a complete loss of freedom of thought, whether this other scientist was really aware or not of imposing his thought. ${ }^{30}$

Mara Beller adds that certain scientists (possibly including Weizsäcker himself) felt guilty for not thinking like Bohr. "Bohr's unpublished correspondence discloses the overwhelming guilt experienced by those physicists who dared to challenge him" (Beller, 1999, p. 274). Experiencing guilt means that sorts of commitments were violated. But the first issue is to know if these were joint commitments between Bohr and his students (or junior scientists) or instead only students' (or junior scientists') unilateral commitments to Bohr's principles. In the former case, it would have meant that these students would have felt committed to the principles only to the extent that Bohr's reciprocally seemed committed to the same principles, which is plausible. But the idea of joint commitment also implies that Bohr's would have felt himself committed to these principles under the conditions that his students seemed committed as well (interdependence), which is quite unlikely. Consequently, although there is no absolute evidence of any kind, unilateral commitments only of the students are much more likely than (reciprocal and interdependent) joint commitments of everyone. And these cases are situations in which Bohr seems to have more or less consciously imposed his views.

Bohr's case is surely an extreme case (characteristic of charismatic leaders) but extreme cases of this kind are not rare in the social sciences. I would like to refer to another case chosen in a group I have also already referred to, not only because this example is less extreme but also because it illustrates another possible aspect of unilateral commitments hidden under apparent joint commitments. It is the case of Ludwig von Mises, one of the main representatives of the Austrian School of Economics, especially when he emigrated to the U.S.A. during the Second World War

\footnotetext{
${ }^{29}$ Beller (1999) examines another similar case, Jesse Du Mond's (p. 274).

${ }^{30}$ Weizsäcker later tried to unify science and religion. See Weizsäcker (1980). The complementary principle's extensions provided by Bohr himself opened the door to such attempts.
} 
(and long before the foundation of the von Mises institutes by his followers). Mises was allegedly very authoritative with everybody (Caldwell, 2004). But for years he entirely rejected one of his closest and most brilliant students, Fritz Machlup, just because the latter publicly defended scientific views (more exactly epistemological views) different from his. Mises is reported to have been indignant on this occasion. ${ }^{31}$ This indignation reveals that he thought Machlup was committed to the same theories as he himself was.

Actually, one could argue that if there was a joint commitment to certain theoretical principles, e.g. the Austrian principles (methodological individualism, subjectivism, and focus on processes more than on equilibrium states, Boettke, 1994b) or to certain more specific principles characteristic of the von Mises micro-community (see below), Mises might have been right to reproach Machlup. But the first point is to know whether von Mises really felt jointly committed to these principles with Machlup and possibly with other junior scientists. As there is no evidence of such a joint commitment feeling (unlike what emerges from the French school of sociology materials, for example), it is much more psychologically plausible to think that von Mises did not feel himself jointly committed to these principles, although he expected that Machlup felt committed to them. On the other hand, according to Fritz Machlup's memories (Machlup, 1981), Machlup seems to have understood he should have felt committed to these principles only when Mises heaped reproaches on him. ${ }^{32}$ Thus, the commitments at stake were at least not "common knowledge" with respect to Mises and Machlup, which would have required that the commitments be "out in the open" with respect to them (Gilbert, 1996, p. 198).

But, what is specifically interesting in this case is that the "clash" between von Mises and Machlup happened on the significance of von Mises' specific idea, the idea that the rationality principle, taken as the most relevant principle in social sciences by many scientists, was analytical, that is that human action has to be considered as a priori rational. For Mises, if certain behaviour was not rational, it was not specifically human and did not require specific explanation from the social sciences, but if it was human, it was rational by definition (Mises, 1966). But as Rizzo (1990) has brilliantly shown, what can be discussed - even if one accepts the rationality principle as the "core" of a research programme — is the content of the notion of rationality. And the various meanings this notion can take constitute the "protection belt" of the programme, to use Lakatos's terms. The clash between von Mises and Machlup took place when Machlup suggested such a modification of the rationality principle's meaning, in the light of the growing empiricist criticisms against Mises's "a priorism" (Boettke, 1994a). It is surely a case where collective deliberations leading to decisions as to the relevance of the modification of certain principles of a paradigm would have made sense. But it was not what happened under von Mises's "reign" since Mises seems not to have been able to accept any modification of the supposedly shared principles.

\footnotetext{
${ }^{31}$ There was also another similar occasion (regarding the right policies to encourage on the gold standard issue), in which there was a clash between von Mises and Machlup; see Bouvier (2007b).

${ }^{32} \mathrm{I}$ addressed this specific issue in detail in Bouvier (forthcoming). See also Bouvier (2007b).
} 
In this part, I have set forth two kinds of what I consider as illegitimate constraints imposed upon members of a scientific community within the context of commitments that seem at first sight to be joint commitments but reveal themselves to be more plausibly mere unilateral commitments of junior scientists. In one case, the constraint is rather on the content of the commitment: Weizsäcker seems to have almost abandoned confidence in his own thought, entirely submitting it to Bohr's. In the other, the constraint is rather on the procedure: Machlup was reproached by von Mises for either having violated a (unilateral) commitment or not having felt committed since Machlup wanted to initiate modification of the principles.

Now, at this point, I find it useful to introduce more astute moral or ethical conceptions of freedom and liberty than those I have till now implicitly used to investigate more in detail these two kinds of constraints, especially in unilateral commitment contexts (but as well in joint commitments contexts since Como type cases raise problems). It will be the matter of the third part of this paper.

\section{III}

\section{SCIENTIFIC LIBERTY AS ABSENCE OF ARBITRARY CONSTRAINT (DOMINATION)}

Philip Pettit, who is partly interested in the same problem as Gilbert, notably the understanding of Durkheim's intuitions about the possible existence of groups or the relevance of contractualist models (Pettit, 1993, 2003), has elaborated much more on this issue than Gilbert (Pettit, 1999). And as Pettit considers "deliberative" situations (although not specifically in the scientific life contexts), his conceptions of freedom and liberty might help us to refine our ethical intuitions. ${ }^{33}$ I will be led later on to consider new historical cases, but in the meanwhile, I need to consider more general issues on freedom and liberty.

Pettit takes as his point of departure Isaiah Berlin's (1969) famous distinction between two kinds of liberty, positive and negative and wants to introduce a third one. Pettit also introduces a new kind of Republicanism, based on this new kind of liberty, different from the classical Rousseauan tradition that arguably continues with Habermas and enhances positive liberty. Positive liberty is the freedom to decide politically for oneself, that is to be politically autonomous. Rousseau's conception of contractualism is of this kind: citizens obey laws that they have decided on without delegates or any other intermediaries. Habermas's conception of deliberative democracy (Habermas, 1992), just adds to Rousseau's conception the fundamental idea that what really makes the general will a value is the fact that it is obtained through deliberation, that is through an exchange of arguments leading to a decision. If one accepts the idea that there may be deliberation in science, the construction of Durkheim and Mauss's programme of the sociology of categories seems close to this conception, because Durkheim and Mauss seem to have been jointly committed together (there-

${ }^{33}$ To my knowledge, Thagard, one of the leading figure of naturalized social epistemology has not addressed the ethical aspect of cooperation or collaboration in science. See Thagard (1997). 
fore reciprocally and interdependently) without feeling any specific intellectual constraint from the other, as far as one can have a plausible knowledge of this kind of feeling on the basis of their confidences and of their general behaviour. And there is no evidence either that this was different regarding the other members.

But this Rousseau-Habermas normative conception of democracy seems pretty unrealistic for many reasons, of which the Como case is a good illustration. Thus, the Como case suggests that deliberation may be entirely lacking in joint commitment contexts and that the joint commitment may be coerced too. Moreover, as the relations between Bohr and his students in the last stages of the Copenhagen school or between von Mises and Machlup suggest, the joint commitment may be more apparent than real, so that what the junior scientist may have to face is actually a unilateral commitment associated with a constraint either to entirely submit to senior's thought or not to be allowed to participate in the modification of the shared principles.

The Rousseau-Habermas conception of democracy is still unrealistic for other reasons. Thus, as is well known, Berlin also rejects this conception of liberty, which he calls positive liberty, as all the liberals since Benjamin Constant and Tocqueville, mainly because, according to them, it is the door open to the tyranny of the majority upon the minority. ${ }^{34}$ These risks exist as well in the sciences and, for example, a majority may make remedy recommendations in medicine or a specific policy in economics even if the minority strongly disagrees. I will not elaborate more on these cases.

But given that all these reasons are more or less clearly accessible to everyone, it might not be surprising that when a new paradigm arises, scientists often do not jointly - nor unilaterally (if they can) - commit together, contrarily to what Gilbert's model suggests. I will take here two examples, again chosen within the history of the research programmes I have already examined. In these two cases, while the scientists shared some fundamental ideas, they did not jointly commit and neither did they construct a collective research programme in Gilbert's sense of "collective". In these two cases, the collective beliefs or - rather - the collective acceptances were a matter of a "summative account" to use Gilbert's language. Besides, no scientists either unilaterally commit to one another. The issue will be, of course, to know whether this kind of "natural state" is both desirable and often realizable in science.

The first example is the case of the early Copenhagen School, during the few years before the Como conference and the Solvay Congress (which took place both in 1927). According to Mara Beller, and it is a point on which she insists a lot given the historical data at our disposal, although Bohr - not only the oldest of the group but the most famous as well at this period - Heisenberg, Pauli and Dirac shared certain if not very numerous conceptions on quantum mechanics, they did not commit to any collective programme (which does not necessarily exclude external institutional pres-

${ }^{34}$ Obviously, this tyranny is especially hard to support when the minority sincerely thinks that the majority is gravely mistaken. 
sure). ${ }^{35}$ In Berlin's and Pettit's terms, they experienced intellectual negative liberty, that is the independence from any intellectual constraint (even from Niels Bohr), such as in a natural state (in the sense of Hobbes or Rousseau).

The comparison will be perhaps more tangible if I take the Austrian School of Economics also in its earlier period, that is the period of Carl Menger, von Wieser and Böhm-Bawerk (of which von Mises was the most brilliant student). Like Bohr, Heisenberg, Pauli, Jordan and so on, they were not at all jointly committed to any collective programme although Menger, von Wieser and Böhm-Bawerk shared significant conceptions, particularly methodological individualism, subjectivism, focus on processes instead of equilibriums and also what is called the "marginalist" conception of value (Boettke, 1994a). Like Bohr in the early Copenhagen School, Carl Menger was older than his colleagues and much better-known. Nevertheless Menger, Böhm-Bawerk, von Wiese remained independent of each other and Menger did not constrain at all their own projects (nor impose unilateral commitments). ${ }^{36}$ So, they experienced negative liberty in Berlin's sense or freedom as absence of interference in Pettit's sense, that is absence of any (intellectual or institutional) constraint (Boettke, 1994a).

Finally, Philip Pettit has introduced a third conception of freedom and liberty and has described a historical tradition that emphasises this conception, that is neither positive liberty in Rousseau's contractualist sense nor negative liberty or liberty as independence or absence of interference (and consequently any constraint) from others in one's project. This tradition, Pettit states, is closer to Cato's Letters or to the Federalist Papers. The key idea is that liberty is essentially the absence of domination, that is absence of arbitrary constraint in a sense I will specify. This idea is directly opposed to the Hobbesian indifference to coercitive commitments in both senses of coercion (coercion on the procedure and on the content of the commitment). It requires less than autonomy, that is less than joint commitment and therefore less than reciprocal and interdependent commitments. On the other hand, it does not entirely exclude constraint as far as this constraint is not arbitrary (what Pettit calls interference), which means that unilateral as well as joint commitment are not prohibited, if the required commitment does not mean loss of intellectual freedom (what one can call the content condition) and if the commitment is not constrained itself (what can be called the procedural condition).

Where is the place of liberty in this conception of democracy? As in politics Pettit states that liberty is not fundamentally located in the procedures of decision concerning the laws, in a scientific context this is not fundamentally located in the formulation of the goals of the research programmes themselves, which can be formulated by an intellectual leader. But this liberty is situated in the capability at least to publicly contest the attempts, in politics, of the Government — and, in a scientific context, those of the intellectual leader - to impose his view on the members of his

${ }^{35}$ Bohr tried to persuade Heisenberg in 1927, before the Como conference, not to publish his Uncertainty paper, as early as Heisenberg wanted. Heisenberg stated that "perhaps it was also a struggle about who did the whole thing first" (Beller, 1999, p. 138-9).

${ }^{36}$ Unlike Heisenberg and Pauli, they already had a position as full professors. 
team (e.g., see both the Heisenberg and Pauli case at Como, in a joint commitment context and the Weiszäcker case later, in a unilateral context).

One can furthermore argue, as James Bohman (2005) did following Hannah Arendt's intuitions, that this kind of conception is nevertheless slightly too weak and that the democratic minimum requires the right and the capability of initiating modifications (in Law, in a collective research programme _ see the Machlup case). I share Pettit's proposal and Bohman's amendment. ${ }^{37}$

\section{Conclusion}

To conclude, I will state the following propositions. First, the earliest periods both of the Copenhagen school in quantum mechanics and of the Austrian school in economics are evidently characteristic of a scientific revolution, in which one can experience negative liberty. For this reason, these periods cannot probably be taken as references for further scientific development, which require collective planned research. Second, the French school of sociology case seems a very rare case in which members seem to have experienced positive liberty, other cases of joint commitment or apparent joint commitment actually either leading to more or less moderate illegitimate intellectual coercion, as in the case of Bohr at Como, or hiding unilateral commitments leading to more severe cases of intellectual coercion, such as in the cases of the elder Bohr vis-à-vis Weizsäcker (and other junior scientists) and von Mises vis-à-vis Machlup.

The third model of liberty (absence of domination) seems more realistic in science. On the one hand, it does not require a complete absence of intellectual constraint (a certain degree of intellectual constraint might be useful for the scientific progress internal to a paradigm, that is when science becomes "normal science" in Kuhn's sense). It does not require joint commitment either: reciprocity and interdependence of commitments might be too demanding when there is an inequality of competence in a domain. But, on the other hand, this model of liberty nevertheless requires the right and the capability to publicly contest, which Heisenberg and Pauli in Como and Weizsäcker later on were lacking, and the right and the capability to initiate modifications in a research programme, which was missing for Machlup.

\section{REFERENCES}

Beatty, J., 2006, “Making disagreement among experts”, Episteme, vol. 3, n¹, pp. 52-67.

Berlin, I, 1969, Four Essays on Liberty, Oxford, O.U.P.

Besnard, Ph., 1979, "La formation de l'équipe de 1' Année sociologique", Revue Française de Sociologie, XX, pp. 7-31.

Boettke, P. J. (ed.) 1994a, The Elgar Companion to Austrian Economics, Edward Elgar, Aldershot. Boettke, P. J., 1994b, “Introduction” to Boettke, P. J. (ed.) 1994a, pp. 1-6.

Bohman, J., 2005, "Is Democracy a Means to Global Justice? Human Rights and the Democratic Minimum," Ethics and International Affairs 19:1, pp. 101-116.

\footnotetext{
${ }^{37}$ Bohman introduces this idea in the context of a discussion of Habermas' (not Pettit's) ideas.
} 
Born, M. \& Heisenberg, 1927, "Quantum Mechanics” in G. Bacciagaluppi \& A.Valentini, 2006, Quantum Theory at the Crossroads: Reconsidering the 1927 Solvay Conference, Cambridge, Cambridge University Press, pp. 408-447.

Bouvier, A., 2004. "Individual Beliefs and Collective Beliefs in Sciences and Philosophy. The plural subject and the polyphonic subject accounts. Case studies". Philosophy of the Social Sciences, vol. 34, $\mathrm{n}^{\circ} 3$, pp. 382-407.

Bouvier, A., 2007a «Collective Belief, Acceptance and Commitment in Science. The Copenhagen School Example », in Iyuun : The Jerusalem Philosophical Quarterly, vol. 56, pp. 91-118.

Bouvier, A., 2007b, “Qu'est-ce qu'un engagement de groupe en sciences sociales? L'exemple de l'école autrichienne d'économie" in Bouvier, A. et Conein, B. (eds.), 2007, L'épistémologie sociale. Une théorie sociale de la connaissance, Paris, Ed. EHESS/Raisons Pratiques pp. 255294.

Bouvier, A., (forthcoming), "Passive Consensus and Active Commitments in the Sciences", Philosophy of Science Association Congress, Pittsburgh.

Caldwell B., 2004, Hayek's Challenge. An Intellectual Biography of F. A. Hayek, Chicago, The University of Chicago Press.

Cohen, L. J., 1992, An Essay on Belief and Acceptance, Oxford, Clarendon Press.

Durkheim E. and M. Mauss, 1903, "De quelques formes primitives de classification: contribution à l'étude des représentations collectives », L'Année sociologique, VI, pp. 1-79.

Elster, J., 1991, "Arguing and Bargaining in the Federal Convention and the Assemblee Constituante", Working Paper. Occasional papers from the Law School, the University of Chicago.

Gilbert, M., 1989, On Social Facts, Princeton, Princeton University Press.

Gilbert, M., 1993, “Agreements, Coercion and Obligation”, Ethics, n¹03, reprinted in Gilbert 1996, chap. 12 , pp. 281-311

Gilbert, M.,1994, "Durkheim and Social Facts" in W. Pickering and H. Martins, Debating Durkheim, London: Routledge.

Gilbert, M., 1996, Living together. Rationality, sociality and obligation, Rowman \& Littlefield, Lanham.

Gilbert, M. 2000, "Collective Belief and Scientific Change", in Gilbert, M., 2000, Sociality and Responsibility, Lanham, Rowman \& Littlefield (chapter 3).

Gilbert, M. 2002, "Belief and Acceptance as Features of Group", in Protosociology, vol. 16, pp. 35-69.

Gilbert, M., 2006, A Theory of Political Obligation. Membership, commitment and the bond of obligation, Oxford, O.U.P.

Goldman A., 1999, Knowledge in a Social World, Oxford, Clarendon Press, 161-88.

Goldman A., 2002, Pathways of knowledge, Oxford, Oxford University Press.

Gutman, A. And D. Thompson, 2004, Why Deliberative Democracy? Princeton: Princeton University Press.

Habermas, J., 1992, "Further Reflections on the Public Sphere”, in C. Calhoun (ed), Habermas and the Public Sphere, Cambridge Mass.: MIT press

Hanson, N. R., 1958, Patterns of Discovery, Cambridge, Cambridge University Press

Howard, D., 2004, "Who Invented the 'Copenhagen Interpretation': A study in Mythology," Philosophy of Science, $\mathrm{n}^{\circ}$ 71, pp. 669-682.

Kitcher, Ph., 2001, Science, Truth, and Democracy, Oxford, Oxford University Press.

Longino H, 1990, Science as Social Knowledge, Princeton, Princeton University Press.

Longino, H., 2002, The Fate of Knowledge, Princeton, Princeton University Press.

Machlup F., 1981, "Homage to Mises," Hilldale, MI, Hillsdale College, pp. 19-27.

Mauss, M., 1950, Sociologie et anthropologie, Paris, Presses Universitaires de France.

Meijers, A., 1999, "Believing and Accepting as a Group" in Meijers, A. (ed.), Cognition and the Will, Tilburg: Tilburg University Press, pp. 59-71.

Mehra J. and H. Rechenberg, (1982), The historical development of Quantum Theory, New York, Springler-Verlag. 
Merton, R., 1942, "Science and technology in a democratic order", in Journal of legal and political sociology, T.1, pp. 115-126.

Mises (von), L., 1966, Human Action, Chicago, Contemporary books.

Pettit, Ph., 1993, The common mind. An essay on psychology, society and politics, Oxford, O.U.P.

Pettit, Ph., 1999 ( $2^{\text {nd }}$ ed.), Republicanism. A Theory of Freedom and Government, Oxford, O.U.P.

Pettit, Ph., 2003, "Groups with Minds of their Own”, Philip Pettits's Papers, Philip Pettit's Homepage, Princeton University.

Rizzo, M. 1990, "Mises and Lakatos. A Reformulation of Austrian Methodology", in Littlechild (1990), pp. 487-507.

Rousseau, J.-J., 1964 [1762], Contrat Social in Rousseau Euvres complètes, T. III, Paris, Gallimard, Pléiade.

Schmidtz, D., 1990, “Justifying the state ”, Ethics, vol. 101, nº1, pp. 89-102.

Simmons, A.J., 1979, Moral Principles and Political Obligations, Princeton, Princeton University Press.

Simmons, A.J., 1984, "Consent, Free Choice, and Democratic Government”, Georgia Law Review, vol. 18, pp. 809-17.

Sztompka, P., 2007, “Trust in Science”, Journal of Classical Sociology, vol. 7, n², pp. 211-220.

Thagard, P., 1997, "Collaborative knowledge" in Noûs vol. 31, n², pp. 242-261.

Thagard, P., 1998a, "Ulcers and Bacteria I : Discovery and Acceptance". Studies in History and Philosophy of Science, 29, p. 107-136.

Thagard, P., 1998b, "Ulcers and Bacteria II : Instruments, Experiments, and Social Interactions", Studies in History and Philosophy of Science.

Wray, K. B., 2001, “Collective Belief and Acceptance,” Synthese, pp. 319-333.

Weizsäcker, C.F., 1980 [1971], The Unity of Nature, New York, Farrar Straus \& Giroux 